\title{
Ethical Assessment of Blank Consent Forms for Medical Interventions in a Training and Research Hospital in Turkey
}

\section{Tıbbi Müdahaleler için Kullanılan Matbu Onam Formlarının Etik Açıdan Değerlendirilmesi}

\author{
Aslihan AKPINAR ${ }^{1}$ iD, Müesser ÖZCAN² iD, Deniz ÜLKER ${ }^{3}$ iD, Oğuz ÖKSÜZLER ${ }^{4}$ iD \\ ${ }^{1}$ Department of History of Medicine and Ethics, Kocaeli University School of Medicine, Kocaeli, Turkey \\ ${ }^{2}$ Department of History of Medicine and Ethics, Muğla Sitkı Koçman University School of Medicine, Muğla, Turkey \\ ${ }^{3}$ Health Sciences Institute, Muğla Sitkı Koçman University, Muğla, Turkey \\ ${ }^{4}$ Administrative Services Secretary General of the Muğla Association of Public Hospitals, Muğla, Turkey
}

\section{ABSTRACT}

Objective: To assess ethical conformity of consent forms to the ethical standards used for medical interventions in a training and research hospital.

Methods: In this study, the content of blank informed consent forms used for medical interventions in the hospital was categorized under standard topics by the researchers and was assessed according to an updated Turkish Regulation on Patients' Rights, Turkish Medical Association's Code of Medical Ethics, and Ateşman's Readability Formula.

Results: A total of 336 procedure-specific consent forms were used in the hospital. It was observed that the parts rated highest were the aim of the intervention $(>67 \%)$, possible risks ( $>96 \%)$, and the name/surname and signature of the responsible physician $(>94 \%)$ and the patient $(>94 \%)$. All consent forms displayed difficult readability levels $(>94 \%)$. There were some favorable topics, such as the right not to know (or not to be informed) of the patient, as well as the items that may lead to the breach of autonomy of the patient, such as the signature of personnel other than the physician.

Conclusion: Updating the consent forms within the frame of items recommended in this paper will ease the arrangement of the content in accordance with ethical and legal standards.

Keywords: Medical ethics, informed consent, consent forms, readability öz

Amaç: Bir eğitim ve araştırma hastanesinde tıbbi girişimler için kullanılan matbu onam formlarının etik standartlara uygunluğunu değerlendirmek

Yöntemler: $\mathrm{Bu}$ araştırmada bir eğitim ve araştırma hastanesinde tıbbi müdahaleler için kullanılmak üzere hazırlanmış matbu aydınlatılmış onam formlarının içeriği araştırmacılar tarafından sınıflandırıldı. Hasta Hakları Yönetmeliği ve Hekimlik Meslek Etiği Kuralları'na uyumu, Ateşman Okunabilirlik Formülü ile okunabilirliği ve tıbbi terminoloji kullanımı açısından değerlendirildi.

Bulgular: Araştırma süresinde hastanede kullanılan işleme özgü onam formu sayısı 336 idi. Araştırmacılar tarafından sınıflanan içeriğe göre müdahalenin amacı $(>67)$, riskleri $(>96)$ ve sorumlu hekimin adı-soyadı (>94) bölümleri en sık tekrarlanan bölümlerdi. Tüm bilgilendirme ve onam formlarının okunabilirlik seviyesi "zor" idi (>94). Formların içeriğinde hastanın bilmeme hakkını vurgulayan önemli bölümler olduğu gibi hasta dışında bir personelin imzası gibi hasta gizliliğini ihlal edebilecek bölümler de vardi.

Sonuç: Kullanılan matbu onam formlarının mevzuat çerçevesinde güncellenmesi ve anlaşılırlığının sağlanması aydınlatılmış onamın hayata geçirilmesinde yaşanan sorunları azaltabilir.

Anahtar sözcükler: Tıp etiği, aydınlatılmış onam, onam formları, okunabilirlik

\section{Introduction}

Informed consent is defined as the process whereby individuals with decision-making capacity give their permission for a given procedure after receiving information and confirming that they understand the diagnosis, treatment, and alternative treatment options, as well as the possible positive or negative outcomes (1). The main objective is to protect an individual's autonomy, so the process allows patients to exercise their right to decide (2). This is achieved by giving information to a competent and willing patient who can understand the information, which is demonstrated through the concepts of competence, voluntariness, disclosure and recommendation, understanding, decision making, and authorization.

Cite this article as: Akpınar A, Özcan M, Ülker D, Öksüzler O. Ethical Assessment of Blank Consent Forms for Medical Interventions in a Training and Research Hospital in Turkey. Bezmialem Science 2018; 6(4): 294-300. 
While there is no consensus regarding definitions of many issues in medical ethics, informed consent has had relatively standard ethical, legal, and institutional definitions in national and international regulations for a long time (3). However, probably based on the difference between the theory and application of the informed consent process (4), there are still controversies regarding informed consent. As Beauchamp and Childress observed (5), informed consent is discussed and used with two different meanings. The first describes the process whereby the individual autonomously gives authorization for a medical intervention (or participation in research) through the act of informed and voluntary consent, which occurs by doing more than expressing an agreement or complying with a proposal. The second meaning describes the process whereby professionals obtain legally and institutionally valid consent from patients to perform diagnostic and treatment procedures, but that does not require patient autonomy (5). Indeed, consent forms are only able to show that information has been given (and at best, that information has been given clearly) but does not provide any evidence that the patient is competent or consents voluntarily.

Within this framework, it is possible to separate the empirical research about informed consent into two broad subjects. The first is concerned with whether consent is an ethical symbol of autonomy and how this is relevant to the process of informed consent in terms of disclosing information, understanding information, competence, voluntariness, and authorization. The second is concerned with the physical written consent forms, which relate to the elements of disclosing information and authorization and are the focus of this study.

In Turkey, there are no requirements concerning the form of informed consent needed for medical interventions, except for cases included in specific legislation, such as major surgical procedures, pregnancy termination, organ transplantation, and genetic testing (3). Nevertheless, the informed consent process in Turkey typically entails obtaining a signed written consent form in which the focus is on explaining the risks of the procedure. However, Article 26 was added to the Regulation of Patients' Rights (6) in 2014 (7) (hereinafter referred to as the Regulation), and this article specifically required a consent form for procedures, stating the following: "For the medical interventions that are seen as medically possible to give rise to unconformity with the cases foreseen in the legislation, the consent form, including the information stated in the 15 th article, is prepared by the health care institutions." This article includes information about exceptions and how many copies of a consent form should be prepared and kept. It is foreseeable that this article will lead to expansion in the use of written consent forms that are currently used. The Regulation also outlines the requisite content of information in consent forms, thereby lending support to the ethical and legal standards of the Turkish Medical Association's Code of Medical Ethics (hereinafter referred to as the Code) (8). Over the last few decades in Turkey, although studies have been conducted on how health care professionals obtain or should obtain informed consent $(2,9-15)$, there have been few studies on the content, readability, or conformity of the consent forms to ethical guidelines (16-18).

In this study, we aimed to assess the conformity to ethical standards of blank informed consent forms used for medical interventions in a hospital in Turkey.

\section{Methods}

This study was conducted between August 2015 and January 2016 in an affiliated 500-bed training and research hospital in the Aegean Region of Turkey. All informed consent forms used in the hospital were assessed. The consent forms were typically prepared by the physician who conducted the procedure or by the department in which the procedure was conducted. Even if the forms by Turkish Society of Cardiology were taken as reference for some forms, there was no standard determined by the hospital. Any forms prepared and updated by physician(s) or department(s) were sent to the Quality Assessment Department where the consent forms were archived online to be printed out when requested (this added the corporate logo of the hospital to the forms and formalized them). A permission to conduct this research was obtained from the General Secretary of the Public Hospitals Association, and consent forms were obtained from the Quality Management Unit of the hospital with the consent of the Head Physician.

First, all forms were collected and grouped by two researchers (MO, DU) into three categories, as follows: (i) consent forms for surgical treatment; (ii) consent forms for nonsurgical treatment; and (iii) consent forms for diagnostic procedures. Then, forms were reviewed in each group, and headlines of the information were written. Next, we prepared a checklist of the information in the three main groups to aid standardization; to do so, information in the forms was assessed as either available or not available. The frequencies and percentage distributions of the obtained data were taken.

Second, all forms were assessed using the Microsoft Office Word, and the words were automatically counted. The readability level of each consent form was assessed using the Ateşman Readability Formula in which the readability level of the text was calculated based on the length of words as the number of syllables and the length of sentences as the number of words according to a 5-point scale ranging from very easy to very hard (16).

\section{Statistical Analysis}

The frequencies and percentage distributions of the obtained data were calculated using an Excel Sheet.

\section{Results}

The hospital provides health services via 14 surgical clinics and 13 internal medicine clinics, each of which provides procedure-specific forms. The total number of forms used in 
the hospital in August 2015, as assessed in this paper, was 336; this comprised 267 forms for surgical treatments, 37 for nonsurgical treatments, and 32 for diagnostic procedures. The Orthopedic Department produced the largest number of forms (63 different treatments), while the department of cardiovascular surgery produced the fewest number of forms (seven different treatments).

When the content of the information part of the forms was assessed (Table 1), it was seen that the parts that were given the highest rate in all three groups forms (surgical, nonsurgical, diagnostic) were first the possible risk of the intervention (97.0\%, 97.3\%, 96.9\%, respectively) and second the aim of the recommended intervention $(70.4 \%, 67.6 \%, 75.0 \%$, respectively). The third highest rated part for surgical, nonsurgical, and diagnostic forms were the recommended treatment method $(50.6 \%, 54.1 \%, 59.4 \%$, respectively). There is no other shared title that scored above $50.0 \%$, except the title that was used for authorizing the physician if additional in-

Table 1. Content of the information part of informed consent forms used for medical interventions

\begin{tabular}{|c|c|c|c|c|c|c|}
\hline \multirow[t]{2}{*}{ Subjects } & \multicolumn{2}{|c|}{ CFST $n=267$} & \multicolumn{2}{|c|}{ CFNT $n=37$} & \multicolumn{2}{|c|}{ CFDP $n=32$} \\
\hline & n & $\%$ & $\mathrm{n}$ & $\%$ & n & $\%$ \\
\hline Patient declaration regarding his/her health status & 76 & 28.5 & 12 & 32.4 & 9 & 28.1 \\
\hline Rejection of the information & 11 & 4.1 & 7 & 18.9 & 2 & 6.3 \\
\hline Diagnosis & 90 & 33.7 & - & - & - & - \\
\hline Aim of recommended procedure & 188 & 70.4 & 25 & 67.6 & 24 & 75.0 \\
\hline Expectations-how to prepare & 67 & 25.1 & 13 & 35.1 & 12 & 37.5 \\
\hline Expectations-recovery & 98 & 36.7 & 11 & 29.7 & 11 & 34.4 \\
\hline Application type of the intervention & 135 & 50.6 & 20 & 54.1 & 19 & 59.4 \\
\hline Period of the intervention & 131 & 49.1 & 11 & 29.7 & 16 & 50.0 \\
\hline Benefits of the intervention & 34 & 12.7 & 9 & 24.3 & 15 & 46.9 \\
\hline Risks of the intervention & 259 & 97.0 & 36 & 97.3 & 31 & 96.9 \\
\hline Natural course and risks of no intervention & 146 & 54.7 & - & - & - & - \\
\hline Additional interventions that may be required during the intervention & 91 & 34.1 & - & - & - & - \\
\hline Authorizing physician if additional intervention is necessary & 185 & 69.3 & 13 & 35.1 & - & - \\
\hline Treatment options & 89 & 33.3 & 8 & 21.6 & 4 & 12.5 \\
\hline Benefits and risks of treatment options & 35 & 13.1 & 2 & 5.4 & - & - \\
\hline
\end{tabular}

Table 2. Content of consent part of informed consent forms used for medical interventions

\begin{tabular}{|c|c|c|c|c|c|c|}
\hline \multirow[t]{2}{*}{ Subjects } & \multicolumn{2}{|c|}{ CFST $(n=267)$} & \multicolumn{2}{|c|}{ CFNT $(n=37)$} & \multicolumn{2}{|c|}{ CFDP $(n=32)$} \\
\hline & $\mathrm{n}$ & $\%$ & $\mathrm{n}$ & $\%$ & $\mathrm{n}$ & $\%$ \\
\hline Name/surname, signature of the responsible physician & 259 & 97.0 & 35 & 94.6 & 31 & 96.9 \\
\hline Contact information of responsible physician & 2 & 0.7 & 4 & 10.8 & 2 & 6.3 \\
\hline Name, surname, and signature of the personnel other than physician & 12 & 4.5 & 4 & 10.8 & 4 & 12.5 \\
\hline Summarizing content of the information & 69 & 25.8 & - & - & 1 & 3.1 \\
\hline Forming subtitles and offering option for consent & 232 & 86.9 & 31 & 83.8 & 21 & 65.6 \\
\hline Permission for recording operation for training purpose & 201 & 75.3 & 8 & 21.6 & 3 & 9.4 \\
\hline Withdrawal right of informed consent & 70 & 26.2 & 20 & 54.1 & 15 & 46.9 \\
\hline Name, surname, and signature of the patient & 264 & 98.9 & 35 & 94.6 & 32 & 100 \\
\hline Name, surname, signature of the proxy of the patient & 239 & 89.5 & 33 & 89.2 & 30 & 93.8 \\
\hline Other (name, surname, and signature of the witness) & 167 & 62.5 & 23 & 62.2 & 2 & 6.3 \\
\hline Other (name, surname, and signature of the translator) & 114 & 42.7 & 4 & 10.8 & 16 & 50.0 \\
\hline
\end{tabular}


tervention is necessary. This title was only present in $69.3 \%$ of the forms for surgical treatments, (Table 1).

In the consent, the part name-surname and signature of the patient $(98.9 \%, 94.6 \%, 100 \%)$ were mostly found in all groups (surgical, nonsurgical, and diagnostic, respectively) of

\begin{tabular}{|c|c|c|c|}
\hline Subjects & CFST & CFNT & CFDP \\
\hline & $\begin{array}{c}(n=\angle 0 /) \\
n(\%)\end{array}$ & $\begin{array}{c}(n=s /) \\
n(\%)\end{array}$ & $\begin{array}{c}(n=3<) \\
n(\%)\end{array}$ \\
\hline \multicolumn{4}{|c|}{ Readability of the Form } \\
\hline Very easy & - & - & - \\
\hline Easy & - & - & - \\
\hline Moderate hard & $108(40.4)$ & $7(18.9)$ & $8(25.0)$ \\
\hline Hard & $142(53.2)$ & $21(56.8)$ & $15(46.9)$ \\
\hline Very hard & $17(6.4)$ & $9(24.3)$ & $9(28.1)$ \\
\hline
\end{tabular}

CFST: consent form for surgical treatment; CFNT: consent form for nonsurgical treatment; CFDP: consent form for diagnostic procedures forms. Then the name-surname and signature of the responsible physician $(97.0 \%, 94.6 \%, 96.9 \%$, respectively), and the proxy of the patient $(89.5,89.2,93.8$, respectively) were mentioned. For surgical (62.5\%) and nonsurgical (62.2\%) treatments forms, the part of name, surname, and signature of the witness were also found at a similar rate (Table 2).

The readability of informed consent forms was assessed by the Ateşman Formula, and it was found that none of the forms were easy. More than half of the surgical and nonsurgical forms' readability levels were hard $(53.2 \%, 56.8 \%$, respectively) and nearly for one-third of diagnostic forms, the level was very hard (Table 3 ).

\section{Discussion}

In this paper, we assessed the ethical conformity of consent forms used for medical interventions in a training and research hospital, which revealed both positive and negative aspects of current consent forms. Based on these findings, we offer recommendations that allow future forms to be made in line with ethical requirements, with greater convenience.

\section{Table 4. Assessment of the content of informed consent forms in terms of the current regulations}

\begin{tabular}{|c|c|c|c|}
\hline Subjects & CFST n (\%) & CFNT n (\%) & CFDP $\mathrm{n}(\%)$ \\
\hline \multicolumn{4}{|l|}{ a) Possible reasons of the disease and how it will progress } \\
\hline Diagnosis and specifications of the disease & $90(33.7)$ & - & - \\
\hline \multicolumn{4}{|c|}{ b) Where and how the medical intervention will be done and expected period } \\
\hline Name and signature of the responsible physician & $259(97.0)$ & $35(94.6)$ & $31(96.9)$ \\
\hline Where the intervention will be done & - & - & \\
\hline Natural course and aim of recommended intervention & $188(70.4)$ & $25(67.6)$ & $24(75.0)$ \\
\hline Recommended treatment method & $135(50.6)$ & $20(54.1)$ & $19(59.4)$ \\
\hline How long it will take & $131(49.1)$ & $11(29.7)$ & $16(50.0)$ \\
\hline Benefits of the intervention & $34(12.7)$ & $9(24.3)$ & $15(46.9)$ \\
\hline \multicolumn{4}{|c|}{ c) Diagnosis and treatment options, benefits, and risks of these options } \\
\hline Treatment options & $89(33.3)$ & $8(21.6)$ & $4(12.5)$ \\
\hline Benefits and risks of the treatment options & $35(13.1)$ & $2(5.4)$ & - \\
\hline \multicolumn{4}{|l|}{ d) Possible complications } \\
\hline Possible risks of the interventions & $259(97.0)$ & $36(97.3)$ & $31(96.9)$ \\
\hline \multicolumn{4}{|l|}{ e) Possible benefits and risks that may occur in case of rejection } \\
\hline Possible risks of no intervention & $146(54.7)$ & - & - \\
\hline f) Significant properties of the drugs to be used & - & - & - \\
\hline \multicolumn{4}{|l|}{ g) Lifestyle recommendations critical for health } \\
\hline The aspects to pay attention to before the intervention & $67(25.1)$ & $13(35.1)$ & $12(37.5)$ \\
\hline The aspects to pay attention to after the intervention & $98(36.7)$ & $11(29.7)$ & $11(34.4)$ \\
\hline \multicolumn{4}{|l|}{ h) Information regarding medical assistance when needed } \\
\hline Contact information of responsible physician & $2(0.7)$ & $4(10.8)$ & $2(6.3)$ \\
\hline
\end{tabular}


When the consent forms in the study were reviewed in terms of each article from the Regulation and Code (Table 4), disease diagnosis was only specified in one-third of the consent forms for surgical treatments. A possible reason for this is that the forms were prepared to be specific for the intervention rather than the disease. But it is important that the first stage of the informing be devoted to the disease or suspected disease of the patient. Therefore, it will be appropriate to add section titles "Diagnosis and Specifications of the Disease" and "Suspected Disease" for diagnostic tests to be manually completed during the process of completing the consent forms.

The second stage of obtaining informed consent then concerns information about the intervention itself. None of the consent forms provided information concerning where the intervention will be done, as foreseen by the Regulation. However, neither the legislation nor the forms seemed sufficient for giving appropriate information about the intervention. Future forms would be improved by including the section titles similar to "recommended treatment method type," "aim," "by whom, as well as where and how, it will be conducted," "how long it will take," "the chance of success," and "possible complications." Such an approach would combine the requirements of the Code, the Regulations, and the useful information within current forms. Receiving input from professional associations about the success rates of the intervention and the complication rates will make the forms more appropriate.

The most frequently reported $(>90 \%)$ part in the forms for interventions was the section on possible risks/complications. This gives rise to the consideration that such strong emphasis may have resulted from the fallacy that patients may not claim for compensation when they have the risks mentioned. The presence of statements such as

"the patient accepts, declares, and undertakes that he or she will not make any financial and emotional... complaint in the event that the negative outcomes of the procedures come true" supports this assertion. Placing a greater emphasis on the chance of success and the benefits of any intervention during preparation may allow perceptions to change from being there to protect the doctor from later accusations (2).

Information about alternative treatments, benefits, and risks of the treatment and problems that may occur if the intervention is rejected were given limited space on the consent forms in this study. But, in both the Code and the Regulations, the emphasis is put on giving information about the possible outcomes with and without treatment, as well as the possibility of alternative diagnosis and treatment methods. Indeed, such information forms part of any proper informed consent process. In addition, although the specifications of drugs to be used have clearly been emphasized in both documents, and although the Supreme Court has made a decision on this subject (19), none of the forms in this study provided information about this subject. It will certainly be appropriate to add a title to cover this content in future forms. Concerning the need to make critical lifestyle recommendations, different considerations are necessary before and after the interventions. Therefore, it will be appropriate to standardize this for all forms when they are updated. Also, information concerning how to access medical assistance was not available in any of the forms. Even when contact information was given in good faith, only a few forms provided such information.

When all the informed consent forms were assessed together, the part given most attention was the one concerning the possible risks of the intervention. However, despite this, there were many ambiguous statements that were nonspecific, including, "I know there are risks of bleeding and infection relevant to anesthesia (narcosis) that may be seen with all surgical operations."

Overall, most forms seemed to be prepared to ensure that patients knew the risks of a procedure, rather than being designed to obtain true informed consent, as per definitions and standards of national and international ethics regulations. This may lead to clinicians ignoring the health status and disease of their patient, including information specific to the patient, as was seen in our study, even when using standard printed consent forms specific to the medical procedure, which may be beneficial (20). Therefore, it will be appropriate to update the content of forms with the detail in the Regulation and Code as the standard printed content, leaving space for clinicians to manually add details about the diagnosis and drugs. Additional information about the success rates, complication rates, alternative treatments, and benefits and risks needs to be obtained.

Based on the assessment of the consent section of the consent forms, Article 20 of the Regulation and Article 27 of the Code were relevant to patients who refuse to receive information. However, there was little acknowledgment of this requirement in the consent forms in our study, even though such a title would remind the physician of the patient's right to information, to withdraw informed consent, and reject treatment. In updated forms, it will be appropriate to include the issue of refusing or withdrawing informed consent as standard. Along with that, it is important to word the topic of consent by a proxy with care, because careless phrasing may lead to a risk that forms will be automatically signed by a relative of a patient (2). This risk could be prevented by including a statement such as, "in cases when the patient is not of age, is unconscious, or may not be able to make a decision, such as in emergency situation" at the beginning of the proxy consent.

Ideally the consent forms should have two signatures belonging to the physicians and the patient. However more than half of the consent forms had places for signing by a witness or health care personal other than the physician. These places were possibly added by the health care institution/professionals with the aim of proving that the consent was taken, but 
they are not requirements of any ethical or legal regulation and have the potential to breach patient privacy when applied. Therefore, it may be appropriate to remove them from the forms.

The most problematic content of the consent forms was where it was stated that "the physician will make decisions when additional interventions are necessary because of complications during the intervention."

The Article 31 of the Regulation clearly defines the necessary additional interventions as "If the intervention is not expanded when a need rises during a medical intervention, and a required medical procedure will lead to loss of an organ or loss of function, the medical intervention may be expanded without requesting further consent" (7).

However, in consent forms, there was a wide variety of statements authorizing physicians to perform additional interventions in most of the surgical treatment forms. These include the following:

"Except for previously planned diagnostic and treatment applications, I know, understand, give consent, and request that various procedures be done, even at different clinics or by different disciplines."

"I authorize my doctors to perform all different and additional operations that they deem necessary"

"I authorize the doctors and their assistants to make necessary assessments and apply these procedures based on their occupational knowledge. The authorization given in this paragraph includes situations that my doctor may not reasonably anticipate at the beginning of the operation, but that subsequently require treatment."

Notwithstanding that such an indefinite authorization is neither ethically nor legally valid, it is inappropriate to request such authorization in the forms because patients may assume that it abolishes their future right to complain.

Concerning the assessment of the readability of the consent forms, how the information is given is as important as the information itself. Both the Regulation and the Code emphasize the need to give information in a way that is clearly understandable by patients. This "understandability" corresponds to the readability of a consent form. Readability refers to the following characteristics: (i) the ease of reading the printed manuscript; (ii) the ease of reading the content; and (iii) the ease of comprehension and understanding, based on the writing format (21). Therefore, it is necessary to use plain language and reduce the use of medical terminology.

Ateşman's readability test is relevant to the third meaning of readability. Assuming no direct correlation with education level, readability was ordered in five steps from very easy to very hard, and most forms (49\%) were categorized as hard to read. Thus, consent forms were not legible, even from the perspective of this limited assessment. However, other variables are important, including the competence of the patient, where he or she read the form, when the form was given [e.g., the latest time should be $24 \mathrm{~h}$ before a procedure (22)] and how eager the patient was to take information [e.g., women have been shown to be more curious than men (23)]. Research is needed to determine what additional factors affect the readability and understandability of consent forms.

\section{Conclusion}

Consequently in this paper, we identified both positive features and some easily improvable problems in our consent forms. Together, these allowed us to make the following recommendations for the preparation of consent forms in the future.

First, adding subheadings to consent forms will ease the arrangement of content within a logical framework. The standard information about the procedure should be printed, and titles should be given to allow handwritten content about factors such as the drugs to be used. All medical topics, such as the success and complication rates, should be written in plain language, have any ambiguous statements removed, and be informed by professional associations (20).

Second, we found that the patient's name and signature may be confused with other signatures that are needed from proxies, personnel other than the physician, and witnesses. Therefore, forms should be printed with a section for the patient's signature, but also with information about the conditions when the proxy's signature, physician's signature, and translator's signature are to be added. Moreover, we recommend removing unnecessary parts, such as those authorizing the expansion of an intervention or where the signature of a witness or person other than the physician is required. However, sections concerning the declaration of the physician, summary of the information given, and patient consent should be retained in future updates. These are important to proving that consent has been taken, and they can help with patient understanding.

Third, our assessment of the readability of consent forms indicates the importance of employing the services of a linguistic expert to assess and revise any updated forms before they are made available for use by patients (24). Fourth, the development of medically, ethically, and legally valid content will require readability and understandability to be considered, using the guidance from studies concerning what information patients are able to understand $(18,25)$.

Ethics Committee Approval: Ethics committee approval was received for this study from the ethics committee of Muğla Sıtkı Koçman University. 
Peer-review: Externally peer-reviewed.

Author Contributions: Concept - M.Ö., D.Ü., O.Ö.; Design M.Ö., D.Ü., O.Ö.; Supervision - A.A., M.Ö.; Fundings - M.Ö., O.Ö.; Data Collection and/or Processing - M.S., D.Ü.; Analysis and/or Interpretation - A.A., M.Ö., D.Ü.; Literature Search - A.A., D.Ü.; Writing Manuscript - A.A.; Critical Review - A.A., M.Ö.

Conflict of Interest: The authors have no conflict of interest to declare.

Financial Disclosure: The authors declared that this study has received no financial support.

Etik Komite Onayı: Bu çalışma için Muğla Sıtkı Koçman Üniversitesi Bilimsel Araştırmalar Etik Kurulu'ndan etik komite onayı alındı.

Yazar Katkıları: Fikir - M.Ö., D.Ü., O.Ö.; Tasarım - M.Ö., D.Ü., O.Ö.; Denetleme - A.A., M.Ö.; Kaynaklar - M.Ö., O.Ö.; Veri Toplanması ve/veya İşlemesi - M.S., D.Ü.; Analiz ve/veya Yorum A.A., M.Ö., D.Ü.; Literatür Taraması - A.A., D.Ü.; Yazıyı Yazan A.A.; Eleştirel İnceleme - A.A.

Hakem Değerlendirmesi: Dış bağımsız.

Çıkar Çatışması: Yazarlar çıkar çatışması bildirmemişlerdir.

Finansal Destek: Yazarlar bu çalışma için finansal destek almadıklarını beyan etmişlerdir.

\section{References}

1. Türk Tabipleri Birliği Etik Kurulu. Türk Tabipleri Birliği Aydınlatılmış Onam Bildirgesi. Türk Tabipleri Birliği Etik Bildirgeleri. 1st ed. Ankara, Turkey: Türk Tabipleri Birliği Yayınları, 2010.

2. Aydın Er R, Özcan Şenses M, Akpınar A, Ersoy N. Ethical problems about informed consent in orthopedics: A sample from Kocaeli. Turkiye Klinikleri J Med Sci 2011; 31: 455-63. [CrossRef]

3. Tümer AR, Karacaoğlu E, Akçan R. Problems related to informed consent in surgery and recommendations. Turk J Surg 2011; 27: 191-7. [CrossRef]

4. Watson K. Teaching the tyranny of the form: informed consent in person and on paper. Narrat Inq Bioeth. 2013; 3: 31-4. [CrossRef]

5. Beauchamp TL, Childress JF. Principles of Biomedical Ethics. 6th ed. New York, Oxford, USA: Oxford University Press; 2009.

6. Ministry of Health. Legislation of Patient Rights. Official Gazete, Date: 01.08.1998; Issue: 23420.

7. TC Sağlık Bakanlığı Hasta Hakları Yönetmeliğinde Değişiklik Yapılmasına Dair Yönetmelik. Resmi Gazete, Tarih: 08.05.2014; Sayı: 28994

8. Türk Tabipleri Birliği. Hekimlik Meslek Etiği Kuralları. Ankara, Turkey: Türk Tabipleri Birliği Yayınları, 2010.
9. Ersoy N. Klinik etiğin önemli bir sorunu: Aydınlatılmış onam. T Klin Tibbi Etik 1994; 2: 131-6. 10. Beyaztaş FY, Demirkan O. A survey for informed consent before surgery. Adli Tıp Bülteni 2001; 6: 76-80.

11. Ertem A, Yava A, Demirkılıç U. Determination of the opinions and suggestions of the patients undergoing cardiac surgery on preoperative informed consents. Türk Göğüs Kalp Damar Cerrahisi Dergisi 2013; 21: 378-91. [CrossRef]

12. Sahin N, Oztürk A, Ozkan Y, Erdemir AD. What do patients recall from informed consent given before orthopedic surgery? Acta Orthop Traumatol Turc 2010; 44: 469-75. [CrossRef]

13. Ören E, Eren CS, Yeşildere FB, Erdoğan N. Informed consent of contrast media applications in radiology: assessment of comprehensibility and the anxiety of the patients. Tepecik Eğit Hast Derg 2010; 20: 122-30. [CrossRef]

14. Türk Y, Makay Ö, İçöz G, Akyıldız M. How informed are endocrine surgery patients about the risks of surgery after approving an informed consent? Turk J Surg 2014; 30: 93-6. [CrossRef]

15. Yıldırım G, Bilgin I, Tokgöz H. Are in surgical clinic health workers' views and practices related to the informed consent consistent with each other? Cumhuriyet Medical Journal 2014; 36: 451-8. [CrossRef]

16. Boztaş N, Ozbilgin Ş, Oçmen E, Altuntaş G, Ozkardeşler S, Hancı V, Günerli A. Evaluating the readability of informed consent forms available before anaesthesia: A comparative study. Turk J Anaesth Reanim 2014; 42: 140-4. [CrossRef]

17. Küçüker $H$. Are informed consent forms sufficient in patients who undergone surgical interventions. Nobel Med 2012; 8: 403.

18. Su M, Pamuk GA, Erden IA, Aypar U. Genel Anestezi Uygulanacak Nöroradyoloji Hastalarında Bilgilendirme Formunun Anlaşılabilirliğinin Değerlendirilmesi. Türk Anest Rean Der Dergisi 2009; 37: 69-73.

19. TC Yargitay 13. Hukuk Dairesi E. 2006/10057 K. 2006/13842 T. 19.10 .2006

20. Mussa MA, Sweed TA, Khan A. Informed consent documentation for total hip and knee replacement using generic forms with blank spaces. J Orthop Surg (Hong Kong) 2014; 22: 2147. [CrossRef]

21. Temur T. Okunabilirlik (Readability) Kavramı. Türklük Bilimi Araştırmaları 13(13), 169.

22. Emre O, Sert G. Patient Rights Requirement Main Document Rome, November 2002. TJOB 2014; 1: 198-205.

23. Knepp MM. Personality, sex of participant, and face-to-face interaction affect reading of informed consent forms. Psychol Rep 2014; 114: 297-313. [CrossRef]

24. MacDougall DS, Connor UM, Johnstone PA. Comprehensibility of patient consent forms for radiation therapy of cervical cancer. Gynecol Oncol 2012; 125: 600-3. [CrossRef]

25. Arnander M, Teoh V, Barabas A, Umarji S, Fleming A. Improved patient awareness and satisfaction using procedure specific consent forms in carpal tunnel decompression surgery. Hand Surg 2013; 18: 53-7. [CrossRef] 